\title{
Polygamy (polyandry \& polygyny): Yes or No?
}

\author{
J.M. Johan Ras' \\ Department of Criminal Justice, University of Zululand \\ jras@pan.uzulu.ac.za
}

\begin{abstract}
This paper discusses polygamy in the light of the Bible and the Constitution of the Republic of South Africa (Act 108 of 1996). A careful reading of the context (lexical-syntactical analysis) and the broader context (historical-cultural background) of especially the Old Testament reveals that polygyny was not prohibited during ancient times, but was an acceptable practice within Israelite/Jewish communities. Although the practice of polygyny can be criticised, the validity of this belief and/or custom cannot and must not be denied on Biblical grounds. Act 108 of 1996 (section 9.3), dealing with the Bill of Rights of every South African, explicitly states that the state may not unfairly discriminate against anyone inter alia because of their religion, belief, custom, or culture. I recommend that believers/churches must respect those who believe that this practice is from God, and must stop overemphasising monogamy as the only valid marital/cohabitation custom. The Biblical authors, and by implication those drawing up the Constitution, have given everyone the freedom to choose for themselves how many wives they may have. Although polyandry is not mentioned in the Bible, the practice of this belief/custom also cannot be denied. Women have the freedom to practise what they believe is the best for them in their particular situation. Like polygyny, the practising of polyandry cannot be denied on legal grounds (cf. Act 108 of 1996, section 9.3) when it forms part of a person's religion, belief, or custom.
\end{abstract}

Keywords: Poligamy, polyandry, polygyny, old testament, South Africa

\section{Introduction}

Michael Rhum wrote in The Dictionary of Anthropology in 1997 that polygamy is the institution of plural marriage that permits individuals to have more than one spouse. It encompasses both polyandry (to have many men/husbands) and polygyny (to have many women/wives) (Rhum 1997:366). While polygyny was an oriental custom during the time of the Bible, Wright and Thompson (1980, Vol. 2:954-955) are of the opinion that, on economic grounds, it was probably found more among the well-to-do than among ordinary people. In Deuteronomy 17:17, for example, the Hebrew kings are warned against having too many wives, because, according to the immediate context it is pictured that many horses, women, silver and gold may lead a king away from Jahwe.

\section{Polygamy in the Old Testament}

There are many examples in the Old Testament of men who took more than one wife. No matter how one would like to explain this institution, custom or socially-accepted tradition, by referring to a second wife, concubine or female slave, the fact remains that polygamy was an acceptable and ordinary custom - something that cannot and must not denied on linguistic, exegetical, theological, archaeological, historical, and cultural-anthropological grounds.

According to the Genesis narrative, Lamech (Gen. 4:19), who was the great great grandson of Cain, was the first to take two wives, namely Ada and Silla. Cotextually, just as Eve became pregnant and gave birth to Cain, and said, "With the help of the Lord I have brought forth a man", so Ada and Silla, could, by implication, say the same, when they bore Lamech three sons and one daughter (Gen. 4:I-2, 19-22). One must not think that Lamech was bad because he was a family member of Cain who had murdered Abel, his brother. The Genesis narrator did not condemn Lamech's behaviour in taking two wives.

In fact, in this story it is pictured that Lamech's three sons respectively became the leaders of those living in tents, raising livestock, those playing musical instruments, and those who forged all kinds of tools out of bronze and iron. Under the gratia Dei these children were blessed; blessed, because their father and two mothers were blessed by God, the Creator of life (Gen. 4:20-22). This clearly indicates that the narrator did not imply that God was against this practice.

The Hebrew patriarch and father of faith, Abram, who later became Abraham, also had more than one wife. When his first wife Sarai was barren, he followed her advice and took Hagar, the Egyptian maidservant (Gen. 16:2-3). The text says "... she (Sarai) gave her (Hagar) to him (Abram) to be his wife." The Hebrew phrase "le isj-sjah" and the immediate lexical-syntactical context indicates that Abraham took her "to be his wife." The text does not say that he just took her to have a son, but he took her "to be his wife." As a result of this, he got a son, Ishmael, the forefather of the Arabs.

Ishmael was born II years after Abraham received the promise from God that he would have a child (Gen. 12: I-4; 15:5; 16:16). Abraham was 86 years old when Hagar bore Ishmael to him. When Sarai bore Isaac, he was 100 years old

I. Johan Ras is an Associate Professor and Head of the Department of Criminal Justice as well as Vice Dean, nFaculty of Arts, University of Zululand, South Africa. He has two doctoral degrees, one in Theology. 
(cf. Gen. $21: 5$ ). This means that Hagar stayed with Abraham, and he took care of her, for at least 14 years before she was sent away into the desert, by Abraham's first wife, Sarai (Gen. 21:9-21). But even then, the Genesis narrator tells us in a compassionate way how the providential Dei has worked and how God has made provision for her and her son.

Although the author/s does/do not tell us if Hagar again returned to Abraham, Genesis 25:I says that he again took a wife, after Sarah's death. Keturah bore him six sons. Who can say that Abraham's eight children were not the result of a sexually enjoyable and socially-accepted and sharing-caring relationship, within the framework of a polygamous marriage? Abraham's grandson, Jacob, also joined the custom of Laban, an Aramean, and married two wives.

Jacob first married Leah, whom he did not prefer, and then his first choice, Rachel (Gen. 29:16-30). In fact, Jacob worked an additional seven years for Rachel after he already had received Leah. He also received Bilhah and Zilpah, Rachel's and Leah's servants, as wives, when Rachel and Leah wanted him to have more children. The text explicitly says “... that Jacob received Bilhah and Zilpah as wives" (Gen. 30:4 \& 9). The Hebrew phrase "wat-tit-ten-lo le'-ish-sha" without doubt indicates that Jacob received or took Bilhah and Zilpah "to be his wives".

Although Rachel was barren and gave Bilhah to her husband in order to have a child through her, this Biblical example underlines the existence of the well-known ancient custom of taking more than one wife. Since children were important to carry on the family name, a childless wife might allow her husband to have children through her slave. This was legal in civilized Mesopotamia. For example, King Hammurabi, the sixth of II kings in the old Babylonian or Amorite dynasty, who lived approximately 1728 to 1686 BC, has recorded it in what is now the well-known Code of Hammurabi (comp. rule 144-I47, Meek 1995:163 \& 172).

Esau had four wives (Gen. 36:2-3 \& 28:89-9; 36:6) and Moses, the great Israelite leader, had more than one wife (Ex. 2:21; Num. 12:I). Exodus 2:2I talks of his wife, Zipporah, and in Numbers I2:I, the author/s mention/s that "Miriam and Aaron began to talk against Moses because of his Cushite wife, for he had married a Cushite." This Cushite lady was probably from North-Africa (present-day Ethiopia or Southern Egypt) or from the southern parts of Saudi-Arabia. As we read nowhere in the Pentateuch, or get the impression that Zipporah has died before he took the Cushite woman, it seems safe to conclude that she was his second wife; another example of a polygamous relationship.

As mentioned earlier, Deuteronomy 17:17 states that the Israelite king to be appointed in Canaan must not be a man with many Egyptian horses, wives, silver and gold. The reason is that his heart must not be led astray. Deuteronomy 20:14 says the Israelites, during times of war, could "obtain" (the Hebrew word "ta-booz" literally means "seize" or "rob") women and children for them. The Septuagint translated the Hebrew plural words for "the women" ("han-nashshim") in verse 14 with the plural words, which clearly indicate that the Israelites were allowed more than one wife at a time.

While Deuteronomy 24: 5 implies that married Israelite men normally went to make war, Numbers I:45 indicates that they were men above 20 years of age. This means that they were basically married men who went to war and were allowed to obtain additional wives and children if they wanted. Deuteronomy $21: 10-14$ also states that when the Israelites went out to fight against their enemies and they noticed beautiful women among the captives, and were attracted to them, then they could take them home as wives. The immediate context further specifically describes what an Israelite man must do in order to keep this captive woman as his wife. The text even says that he can let her go wherever she wished. This example further emphasizes the freedom of choice that existed, according to the Biblical narrators, during ancient Israelite times, when it came to marriage and practices of cohabitation.

Deuteronomy 21:15 explicitly says that "if" (the Hebrew conditional particle "ki") is used), someone has two wives, one that he loves and one that he does not love, then he must not give the rights of the firstborn to the son of the wife he loves, in preference to his actual firstborn, the son of the wife he does not love. He must acknowledges the son of his unloved wife as the first born, by giving him a double share of all he has, because this son is the first sign of his father's strength, and the right of the firstborn belongs to him. This text is a very clear and explicit reference to polygamy in the Old Testament.

Exodus $2 \mathrm{I}: \mathrm{I}-\mathrm{I} \mathrm{I}$ further indicate that when a master has given a woman to his slave, the woman belonged to the master, except, by implication, when the slave has decided to stay on in the service of his master, after six years of service. Verse 7 further says that a man could sell his daughter as a servant - a clear indication that women were regarded at some time in ancient patriarchal Israel as property. This fact further illustrates the easiness for a man to obtain more wives and to stand in a polygamous relationship. I am also of the opinion that because it was easy to obtain a wife and to multiply wives if one only could afford them, is one reason it was so easy to divorce. It was easy to divorce because it was easy to marry (Deut. 24:1).

The well-known passage in Deuteronomy 25:5-10, dealing with Levirate-marriages ("Levir" is the Latin term for "brother-in-law"), where an Israelite man must take the wife of his deceased brother in order to beget a son to carry on Inkanyiso, Jnl Hum \& Soc Sci 2010, 2(2) 
the name of the deceased in Israel, is yet another example that underlines the existence of socially-accepted customs that are part and parcel of polygamous practices.

Judges 8:30 says that Gideon has 70 sons because, the narrator narrated, that he had many wives. The Hebrew phrase "ki nash-shim rab-boot ha-ju loo" literally means "because there were many women for him." Koehler and Baumgartner (1958:639) in their classic Hebrew lexicon, Lexicon in Veteris Testamenti Libros, correctly translate "nashim" with "Frauen"

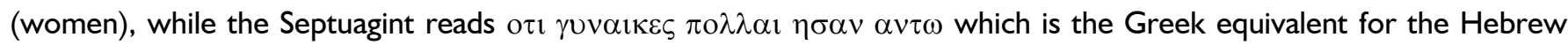
words of Ben Asher's and the Massoretic text "ki nash-shim rab-boot ha-ju loo" as reflected in Biblia Hebraica Stuttgartensia. These words truly reflect the socially acceptable and well-known ancient custom of polygamy in ancient Israel during the times of the Judges.

Another judge or Israelite leader, Jair (Judg. 10:4) had 30 sons who rode 30 donkeys and ruled over 30 towns. It is interesting to note that the 30 sons are mentioned, and especially the 30 donkeys, and not the wives of Jair, who certainly were responsible to bring them into the world and to teach them how to drive and to rule their 30 towns. The book Judges further indicates that another judge, Ebsan (Judges 12:8-9) also had 30 sons and 30 daughters, while another judge, Abdon, had 40 sons (Judges 12:13-14). This number of sons and daughter clearly indicates the presence of many wives, that again indicates the well-known socially-accepted practice of polygamy.

These remarks in the Bible clearly underline the existence of the customary and legal right to have more than one wife if one wishes to do so. After the decisions of the Israelites not to give their daughters to the Benjaminites (Judg. 2I:I-25), because they have raped the concubine of a Levite (Judg. 19-20), this tribe went to Shiloh and each man caught himself a wife, because the narrator tells us that "they did not get wives for them during the war" Judg. 21:20-23).

According to I Samuel I:I-2, Elkana had two wives, Hannah and Peninnah. Literally, "we-loo shet-tee nash-shim" (Hebrew: "There were two wives for him"). Hannah was the mother of Samuel whom God had sent to anoint the first king of Israel, named Saul. Samuel, in other words, in his early years, before going to the temple to serve under Eli the priest, grew up in a polygamous environment. The first king of Israel, king Saul, is pictured as having more than one wife. 2 Samuel 3:7 also talks of Rizpah (literally "Rits-pah"), his concubine, which further indicates the reality of polygamous relations during ancient times.

According to 2 Samuel 3:2-5, well-known king, king David took and had six wives, and when he had fled away from his son Absalom, he had left 10 concubines behind (cf. 2 Sam. 15:16). After the death of Uriah the Hetite, the text in 2 Samuel 12:7-8 tells that God said through the prophet Nathan to David that he (that is "God") gave the house of his master (that is, Saul) to him, and the wives of his master into his lap, as well as the house of Israel and Juda, and if it was not enough, he would have added more such things. It is clear that this particular text is not against polygyny.

Solomon, the great king of Israel, has 1000 wives (I Kings II:I-3). I Kings II:I says that he loved many foreign women. He had 700 wives and 300 concubines. The practice or custom of taking more than one wife was not wrong in itself, but what was wrong, was that he loved them more than the God of Israel, and he also allowed them to bring their gods into Israelite territory.

I am also of the opinion that the reference in 2 Chronicles 28;8 which states that the Israelites had captured 200000 of their brothers, women, sons and daught, and brought them to Samaria, in the time of king Agas, have polygamous undertones (cf. Green 1976:1203). Although Esra 9:2 and 10:2 only talk of the foreign women that the Israelites wrongfully married, because, by implication, their different religious beliefs that were wrong, it is not impossible that some Israelites also could have taken more than one wife - again indicating the acceptable social custom of polygyny in ancient Israel.

\section{Polygamy in the intertestamental period}

While polygamy was an undeniable fact and a socially acceptable custom or institution during Old Testament times, the picture during the intertestamental period does not look different. According to Flavius Josephus (Antiquities of Jewish Wars 17.19), Herod the Great (37-4 BC) had nine wives at one time.

Papyrus discoveries in Egypt (cf. Hunt \& Edgar 1970:ix) without doubt imply the existence of polygyny. The earliest dated Greek papyrus so far recovered is a marriage contract for the year $3 \mathrm{II}$ BC, between Heraclides and Demetria. This contract is part of the Elephantini papyri (I, II, I-I8), as published by O. Rubensohn. Here the contract explicitly states that "It shall not be lawful for Heraclides to bring home another wife ( $\gamma v v \alpha \kappa \alpha \alpha \alpha \lambda \lambda \eta v)$ in insult of Demetria nor to have children by another woman nor to do any evil against Demetria on any pretext" (Hunt \& Edgar 1970:3). This contract explicitly specifies that there must be no other wife - the reason is that it was a normal custom in Egypt (and in the Jewish communities in Egypt and elsewhere) for men, to bring in more than one wife, if they wanted to.

In another marriage contract, between Philiscus and Apollonia, dated $92 \mathrm{BC}$, as part of the Tebtunis papyri (nr. 104) by B.P. Grenfell, A.S. Hunt, J.G. Smyly, and E.J. Goodspeed, it is also recorded that "It shall not be lawful for Philiscus to bring 
in another wife ( $\gamma \nu v \alpha \imath \kappa \alpha \alpha \lambda \lambda \eta v)$ besides Apollonia, nor to keep a concubine $(\pi \alpha \lambda \lambda \kappa \eta v)$ or boy ( $\pi \alpha 1 \delta 1 \kappa o v)$, nor to have children by another woman ( $\varepsilon \xi \alpha \lambda \lambda \eta \varsigma \gamma v v \alpha 1 \kappa \circ \varsigma)$ while Appollonia lives" (Hunt \& Edgar 1970:7).

In the marriage contract between Thermion and Appollonius, I3 BC, Appollonius is legally instructed not to ill-treat

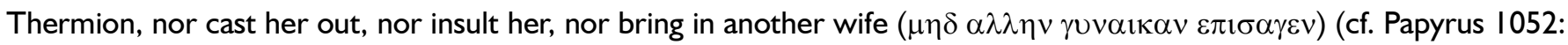
Berlin: Griechische Urkunden - Hunt \& Edgar 1970:II). It is clear that these marriage contracts explicitly stipulated that the bringing in of another wife into the marriage relationship is prohibited.

The above mentioned contracts are all typical examples of contracts in which polygyny inter alia is excluded in a deliberate way. A study of some of the Greek papyrological findings indicates that polygyny, just like monogamy, as stipulated in these contracts, during this time-period, was something done out of one's own free will. The contracts further reveal that the rights for divorce and the conditions for divorce were also explicitly given before any marriage took place. Everything is based on the free will of both parties, for example, in Papyrus Tebtunis, number I04, it says that "If Appollonia chooses of her own will to separate from Philiscus" (cf. $\varepsilon \alpha \nu \delta \varepsilon$ A $\delta$ o $\lambda \lambda \omega v i \alpha \varepsilon \kappa o v \sigma \alpha \beta o v \lambda \eta \tau \alpha \iota$

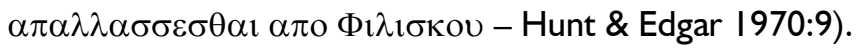

In a marriage contract dated $66 \mathrm{AD}$, that is already far into the New Testament period, in the $13^{\text {th }}$ year of Nero Claudius Caesar Augustus Germanicus Imperator, between Chaeremon (a man of 34 years) and Thaisarion, a lady, it further becomes clear that everyone stands in a relationship through their own free will. Thaisarion had previously lived with Chaeremon as his wife, and they now wanted to marry. Then it was stipulated that "If on a difference arising between them, they separate from each other, whether Chaeremon sends Thaisarion away or she voluntarily ( $\varepsilon \kappa o v \sigma i \omega \varsigma)$ leaves him ... (Hunt \& Edgar 1970:15).

Not only do we find that the marriage contracts in the period just before the New Testament stipulate the way the future marriage must taken place, but we also see during the New Testament era that even matters pertaining to a possible divorce are spelled out. The emphasis in all these contracts, in my opinion, is on voluntary legal obedience (cf. e.g. Papyrus Oxyrynchus nr. 1273, a marriage contract of AD 260; a deed of divorce, I3 BC, Berlin Griechische Urkunden, nr. 1003 - Hunt \& Edgar 1970:16-25).

\section{Polygamy in the time of the New Testament}

We do not have explicit references in the New Testament to polygamy, except for a possible reference in I Timothy 3:2 and Titus I:6. I Timothy 3:I says that "If someone desires to be an overseer, he desires a good job." The text then immediately states in verse 2: "An overseer, then, must be above reproach, the man of one woman, sober, orderly, someone who loves strangers, someone who is able to teach."

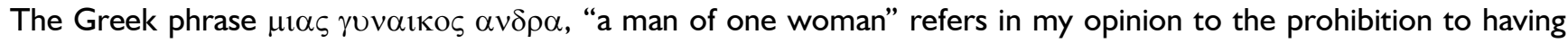
more than one wife. In other words, Paul advised Timothy and Titus to advise those who desired to become overseers not to be come involved in polygyny. It is important to note that this recommendation was not given to any believer, but only to those that desired/aspired to become an overseer.

During the time of the Apostle, what was right and wrong, what to do and not to do, basically depended on what Paul had received from God via subjective and anthropomorphic, unverifiable revelations, other believers, through personal knowledge and experiences, and also through a subjective and intuitive interpretation of the leading of the Holy Spirit, speaking through his conscience. Paul's conscience, in my opinion, was shaped by his earlier Jewish and Hellenistic education, the newly interpreted teachings and revelations of other Christians, and his perceiving and existential personal relationship with the Spirit of God.

This means, that Paul's advice to Timothy and Titus must practically not be seen in an absolute, rigid, legalistic, and prescriptive way, but the "what" of the text must be understood in the light of the "why." In other words, it is not only important to find out what Paul said, but more important to establish why he said it. His advice to the churches and to individuals was shaped by the specific circumstances in which he or the others found themselves, and as a result he advised and prescribed basically what I call situational ethics.

To be an overseer is not to have a certain "status" or "position of authority", in the first place. It means that you will do something. That is why he said in I Timothy 3:I that if any man desires to be an overseer, he desires a fine job. The key words are $\kappa \alpha \lambda$ ov $\varepsilon \rho \gamma o v \varepsilon \pi \imath \theta u \mu \varepsilon \imath$ - "He constantly actively desires an outwardly good job/work" - if I can stress the aktionsartliche meaning of the present tense, indicative, active, of the verb $\varepsilon \pi \imath \theta u \mu \varepsilon \omega$. To be an overseer means that one has to work! There is no time for having more than one woman!

Contextually, to be "irreproachable", is to have one wife, to be sober, to be orderly, to love strangers (hospitable), and to be able to teach. The text also says that this man must be no drinker, no fighter, but gentle, uncontentious, free from the love of silver/money. Someone who manages his own household well, keeping his children under control with all dignity (cf. I Tim. 3:3-4).

Inkanyiso, Jnl Hum \& Soc Sci 2010, 2(2) 
If we erroneously read these verses in a Biblicist and fundamentalistic way, we will be forced to conclude that only elderly men, who already have children and their own households can qualify to become overseers. The same can be said of Titus 1:6 where Paul wrote that an overseer must be the husband of one wife, having children who believe, who are not accused of dissipation or rebellion. This again means the overseer is an elderly person, who has children, children who are grown-ups, children who believe, children who are not, for example, unbelieving rebellious teenagers.

Fundamentalistic thinking and reasoning will lead us into a cul-de-sac because we then forget that Paul's letters are occasional letters; letters that he specifically wrote to congregations from a specific place, at a specific time, to people, situated at a specific place, in order to address their specific needs and/or problems. In this letter he addressed Timothy, who lived in Ephesus (I Tim. 1:3), inter alia to give advice or recommendations concerning the requirements of the overseers to those in the Ephesian congregation (cf. I Tim. 1:3 \& 3:15).

According to the immediate context of I Timothy 3:5-6 it seems there were some new converts in Ephesus who wanted to become overseers but they could not manage their own households in accordance with the expectations of an exemplary lifestyle (cf. Paul's reference in verse 4 to tov idiov oikov). Some of them were also converts (cf. the Greek words $\mu \eta v \varepsilon o \phi v \tau o v$ ). Drinking, fighting, the love of silver or money (cf. the words $\mu \eta \pi \alpha \rho o v v o v, \mu \eta \pi \lambda \eta \kappa \tau \eta v$, $\alpha \phi 1 \lambda \alpha \rho \gamma u \rho o v$ in I Tim. 3:3), the existence of many silversmiths like Demetrius who had made money by manufacturing silver shrines for the goddess Artemis or Diana (cf. Acts 19:24-28), the presence of the temple of Artemis or Diana, with probably hundreds of religiously dedicated female prostitutes who were going around to make followers of Artemis, as well as the many unhealthy false teachers, busy with their never-ending myths and genealogies (I Tim. I:4 uses the words $\mu \nu \theta 01 \zeta \kappa \alpha l \gamma \varepsilon v \varepsilon \alpha \lambda \mathrm{o} \gamma(\alpha 1 \zeta)$, were all matters that shaped Paul's thinking and led to his advice.

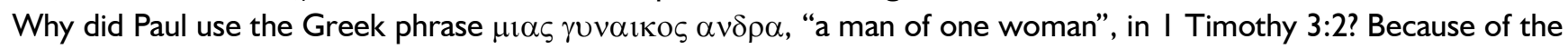
practical situation at grass roots level in Ephesus. Because of the existing problems where those who wanted to become overseers could not manage their own households, could not successfully give direction to their own children, some involved in drinking, others fighting, others trying to make money, some brothers probably being confused by all the false teachings they had heard, and the existence of the temple of Diana/Artemis in Ephesus.

These situational matters, combined with his missionary zeal, his eschatological expectation, and his affective pastoral concern about the growth and edification of the congregation led Paul to write that an overseer must be $\mu 1 \alpha \varsigma$ juvalkos $\alpha \nu \delta \rho \alpha$, a "man of one woman" (a literal translation of the Greek phrase). Paul did not want people to get involved in what we can call wordly affairs (cf. I Cor. 7:26-35). To look for more wives when you already have one, and when you already cannot control or manage your own household, practically means you are simply looking for further trouble. Therefore, an overseer "must be the man of one woman".

The same can be said about Titus I:6. Paul left Titus on the island of Crete to straighten out what was left unfinished and to appoint elders in every town. The practical problems at grass roots level probably include, as far as I can reconstruct the broad historical-cultural context as we find it in the immediate textual context, dispersed Christians, spread all over the island, living in different towns (Tit. I:5), false religious teachers (Tit. I:9), who were probably Jews (Tit. I: 10, 14), idle gluttons, probably hellenistic Cretans, who love to drink, to fight, to pursue dishonest gain, and to talk about godly things, without setting a good example - people who are polluted in their minds and in their conscience (Tit. I:I5).

Because of these very important matters that weakened the Cretan church, as well as Paul's missionary zeal that took him away from Crete, probably to Macedonia (cf. Tit. 1:5), his eschatological expectation that Jesus could come at any moment (Tit 2:13), and the affective urgency and personal desire to straighten out all the problems at Crete, knowing that he needed Titus to come to him to the harbour city of Nicopolis in Macedonia (Tit. 2:13), are all matters that, in my opinion, had influenced and filtered Paul's thoughts in order to lead him to say what he said.

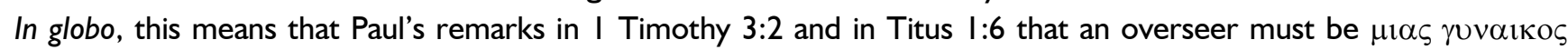
$\alpha v \delta \rho \alpha$, a man of one woman, were to discourage a man who wanted to become an overseer and who already had one woman from getting another one. In the light of the different and practical problems that the believers, especially Timothy and Titus, experienced in Ephesus and on the island of Crete at grass roots levels, and in the light of Paul's view of Jesus' imminent coming, and his missionary zeal, that left no room for any matter that had not directly to do with the work of the Lord, it is quite understandable that Paul could give this advice. Owing to the fact that he (an overseer) was an overseer, this meant that he had to work. Paul did not recommend that the acquiring of more women, when a man already had one, at that stage, would be beneficial to the believer who wanted to become an overseer.

This means that Paul's remarks must not be seen as practically prescriptive and a definite and absolute "no" to any polygamous practices. He recommended it only to those believers in Ephesus and Crete who desired to become overseers, and these recommendations were done in the light of the practical problems that existed in those congregations, and in the light of his eschatological expectation, his missionary zeal, and his pastoral affection. This means 
that these verses today do not exclude any believer, even those who want to become overseers, of taking more than one wife.

\section{Biblical arguments against polygyny}

In the author's opinion there are no convincing, explicit, or direct arguments or thinking against polygyny in the Old or New Testaments. Those exclusively in favour of monogamy normally refers to Matthew 19:3-6 in order to emphasize that the Bible says that God has from the beginning created male and female and that the principle of monogamy is part of God's will, and can be traced back to the time of creation.

From a narrative-critical point of view Matthew places Jesus and his followers in the region of Judea, beyond the river Jordan (cf. Mt. 19:I), when the Pharisees had tested or confronted him by asking, "Is it lawful for a man to divorce his wife for any cause at all?" In Matthew the question concerning divorce is not like the one in Mark, trying to lure Jesus into a political confrontation, but to test him on a debatable point of Old Testament interpretation. This question was put in the framework of a Rabbinic debate, and suits Matthew's portrayal of Jesus as a Rabbi and a teacher. On this question, Matthew's "reconstructed Jesus" did not agree with the Rabbinic school of Rabbi Hillel, who believed that a man may divorce his wife for any reason, but, instead he opted in favour of Rabbi Shammai's argument, that it is only lawful in cases of adultery.

Matthew refers his readers to Genesis 2:24 where it is stated that "He (God) created them from the beginning, made them male and female", and also, "For this cause a man shall leave his father and mother, and shall cling to his wife, and the two shall become one flesh" (cf. Green 1976:6). Consequently, Matthew says, they are no longer two, but one flesh: what God has joined together, let no man separate. It is clear that Matthew's Jesus did not address polygamy, but the specific question, dealing with divorce as an element of infidelity.

Matthew's Jesus is here pictured as somebody who stands up for the rights of women who were treated in an unjust manner and who were subjected to the emotions of their husbands who so easily could write them a letter of divorce, in the light of the Jewish interpretation of Deuteronomy 24:I-4. Matthew's Jesus is here depicted as a man who protected the rights of the women in a patriarchal society.

\section{Polyandry in the Bible}

There are no direct or even indirect references in the Bible to polyandry, but the validity principle for this is I believe clear. If one accepts the existence of polygyny, and I have clearly indicated its existence through the textual references in the Bible, something that cannot be denied on linguistic, exegetical, and theological grounds, then, by implication, one also cannot deny the practice of polyandry as well. What is permissible for men is also permissible for women.

\section{Polygamy and the Constitution of South Africa}

Act 108 of 1996 (section 9.3), dealing with the Bill of Rights of South Africa citizens, explicitly states that:

The state may not unfairly discriminate directly or indirectly against anyone on one or more grounds, including race, gender, sex, pregnancy, marital status, ethnic or social origin, colour, sexual orientation, age, disability, religion, conscience, belief, culture, language, birth.

This practically means that if a person wants to take more than one woman or man because of his/her religion, or his/her beliefs, or simply because he/she just wants to observe and/or follow their particular culture (with all its customs, laws, and traditions), then he/she is absolutely free to do so. The state (and by implication, every individual, church or religious group), may not directly or indirectly discriminate against anyone who does so.

In other words, in the case of President Jacob Zuma or King Goodwill Zwelithini, who each have more than one wife, they are not behaving in an immoral manner or sinning when they exercise their right to take more than one wife, based upon their tradition, belief or custom - it is simply in line of what one finds in the time of the Bible, in ancient Israel and in and around the Mediterranean area and during ancient times. The new Constitution also acknowledges this right, and this needs to be respected by those who do not want to practise this ancient right or tradition, simply because no person's belief, custom or tradition is inferior to any other custom, tradition or belief.

This basically means that every man or woman in South Africa has the freedom to choose as many women or men they want, and to marry, to cohabitate, or to stay with them as long as they want, if he/he has that particular belief/ opinion/conviction. The only thing that is prohibited by the Constitution, as part of section 16 ( $2 a, 2 b$ \& $2 c)$, dealing with "freedom of expression", is that nobody has the right to propagate war, to incite violence, or to advocate hatred, based on race, ethnicity, gender or religion. In other words, nobody must try to incite any person in order to cause harm (cf. Act 108 of 1996, section 16, par. 2, subsection a, b \& c). 


\section{Concluding remarks}

Throughout my paper I have indicated the existence of polygamous practices during ancient times. Although I grew up in a church and legal environment where monogamy was the law and where any white man could be thrown in prison if he had married more than one woman, I am of the opinion that, just as monogamy is regarded as an accepted practice, polygamy must also be regarded as an acceptable practice without regarding those who want to practise this right as people with low moral standards, sexually immoral or careless.

The reason for this is simple - one simply cannot twist the Old and New Testaments, history and ancient traditions, which have guided many other people in the past to have and to experience meaningful and satisfying relationships with those they have chosen. In the light of the Word of God, I cannot deny this socially acceptable practice that has given meaning, hope and direction to many great men and leaders of God who we regard today as men of faith.

Although I do not say that we must become zealous advocates of polygamy in South Africa, I strongly recommend that believers and churches respect those who believe that polygamy is from God and must stop overemphasizing monogamy as the only valid marital or cohabitation practice or custom. The Biblical authors, and by implication those drawing up the new Constitution, have given everyone the freedom to choose for themselves how many women or men they want.

Although many HIV-AIDS activists probably today will favour monogamy and will shout "abstinence and/or condoms" at the same time, the truth is that polygyny was practiced during Biblical times and there are no direct or sound indirect prescriptions that prohibit it. Despite erroneous perceptions, polygamy (polygyny and polyandry) does not automatically lead to the spreading of HIV-AIDS.

Although polyandry is not mentioned in the Bible, the practice of this belief/custom cannot be denied. Just as men today have the right in the light of their own free will to choose as many women as they want, so women have the freedom to practise what they believe is best for them in their particular situations. Like polygyny, the practice of polyandry cannot be denied on legal grounds, in the light of the Constitution, Act 108 of 1996 (section 9.3), when it forms part of a person's religion, belief or custom.

\section{REFERENCES}

Aland, B., Aland, K., Karavidopoulos, J., Martini, C.M. \& Metzger, B.M. 1995. Novum Testamentum Graece. 27. Revidierte Auflage. 3. Druck 1995. Stuttgart: Deutsche Bibelgesellschaft.

Biblia Hebraica Stuttgartensia. 1979. Stuttgart: Deutsche Bibelgesellschaft.

Bower, R. K. \& Knapp, G. L. 1986. Marriage in The international Standard Bible Encyclopedia. Gen. ed. G. W. Bromiley. Vol. 3, KP. Grand Rapids, Michigan: WM. B. Eerdmans.

Gundry, R. H. 1982. Matthew. A Commentary on his literary and theological art. Grand Rapids, Michigan: WM. B. Eerdmans.

Hunt, A. S. \& Edgar, C. C. 1970. Select Papyri. Non-literary Papyri. Private Affairs. English translation by A.S. Hunt and C. C. Edgar. [1932]. London, England: William Heinemann.

Koehler, L. \& Baumgartner, W. 1958. Lexicon in Veteris Testamenti Libros. Leiden: E. J. Brill.

Levinson, D. \& Ember, M. 1996. Encyclopedia of Cultural Anthropology. Eds. D. Levinson \& M. Ember. Vol. 3. New York: Henry Holt.

Meek, T. J. 1995. The Code of Hammurabi in Ancient Near Eastern Texts relating to the Old Testament, pp. 163-172. Ed. J. B. Pritchard. Princeton, New Jersey.

Rhum, M. 1997. Polygamy in The Dictionary of Anthropology, p. 336. Ed. T. Barfield. Oxford, England. Blackwell Publishers.

Septuaginta. 1979. Compiler: A. Rahlfs. Stuttgart: Deutsche Bibelgesellschaft.

The Constitution of the Republic of South Africa. Act 108 of 1996.

Wright, J. S. W. \& Thompson, J. A. 1980. Marriage in The Illustrated Bible Dictionary, p. 955. Ed. J. J. Douglas. Vol. 2. London, England: IVP. 